\title{
Sprawozdanie z działalności Międzywydziałowej Katedry Teologii Katolickiej Uniwersytetu w Białymstoku w roku akademickim 2008/2009
}

Międzywydziałowa Katedra Teologii Katolickiej (MKTK) Uniwersytetu w Białymstoku rozpoczęła kolejny rok akademicki 2008/2009 z ramowym programem dydaktyczno-badawczym wypracowanym w latach ubiegłych, a uszczegółowionym, zaktualizowanym i zaproponowanym na bieżący rok przez jej kierownika, abp. Edwarda Ozorowskiego na posiedzeniu członków zespołu 15 września 2008 roku. $Z$ racji na profil Katedry i jej miejsce w środowisku akademickim Białegostoku podejmowała ona, wzorem lat ubiegłych, inicjatywy, których celem było promowanie nauk teologicznych w środowiskach naukowych miasta, regionu i kraju. W myśl tak rozumianej misji inicjowano i podejmowano współpracę ze środowiskami akademickimi o profilu humanistycznym, filozoficznym i przyrodniczym, czego rezultatem była organizacja i czynny udział w zjazdach, sympozjach i konferencjach o charakterze interdyscyplinarnym, poszukiwanie płaszczyzny dialogu i wypracowanie wspólnego języka przekazu.

Realizując te założenia pracownicy Katedry Teologii Katolickiej wzięli udział w przygotowaniu i przeprowadzeniu w dniach 13-14 listopada 2008 roku w kooperacji z Zakładem Literatury Oświecenia i Romantyzmu Instytutu Filologii Polskiej UwB i Instytutem Filologii Klasycznej Uniwersytetu Adama Mickiewicza w Poznaniu II sesji naukowej realizowanej w ramach projektu badawczego „Starość antyczna - starość romantyczna”. Przedmiotem refleksji nad schyłkowym okresem życia człowieka były tym razem zagadnienia antropologiczne, temat literacki i metafora kultury. Uczestnicy konferencji spojrzeli na tę problematykę w kontekście konfrontacji owego tematu w okresie antycznym, czasach romantyzmu i współczesności. Miejscem obrad była siedziba Instytutu Filologii Polskiej UwB. W pierwszym dniu konferencji Katedrę reprezentował ks. abp E. Ozorowski, który wygłosił referat wprowadzający pt. „Jan Paweł II o starości". Następnego dnia w oparciu o wyniki badań własnych refleksją podzielili się: ks. Adam Skreczko w referacie pt. „Świadomość wartości podeszłego wieku” i ks. Tadeusz Kasabuła referując temat pt. „Człowiek stary w społeczeństwie Polski przedrozbiorowej. Jednego tematu odsłon kilka”. Ożywiona dyskusja po każdej sesji dowiodła aktualności oraz ponadczasowego i ponadkulturowego charakteru podjętej problematyki. 
Międzywydziałowa Katedra Teologii Katolickiej od czterech lat współorganizuje i bierze aktywny udział w corocznych konferencjach naukowoszkoleniowych poświęconych pamięci Elisabeth Kübler-Ross pod hasłem „Życiodajna śmierć” organizowanych przez Zakład Pielęgniarstwa Ogólnego Uniwersytetu Medycznego w Białymstoku (UMB). Współorganizatorami konferencji przeprowadzonej w dniach 12-14 grudnia 2008 roku obok MKTK były Klinika Rehabilitacji Dziecięcej UMB, Instytut Medyczny Państwowej Wyższej Szkoły Informatyki i Przedsiębiorczości w Łomży oraz Polskie Towarzystwo Lekarskie Oddział Białystok. Tematykę tegorocznej edycji obrad określili organizatorzy w pisemnej zapowiedzi wykładów. Stwierdzili tam, że „współcześnie bardzo często myśl o śmierci spychana jest na margines świadomości. Dawniej ludzie umierali $\mathrm{w}$ domu, $\mathrm{w}$ atmosferze ciepła i rodzinnej miłości, otoczeni bliskimi. Z biegiem czasu, wraz z rozwojem medycyny, miejscem śmierci stał się szpital, klinika i hospicjum. Często najbliżsi nie towarzyszą chorym $\mathrm{w}$ tych ostatnich chwilach życia. Zmiana ta doprowadziła do społecznego wypaczenia obrazu śmierci, czego efektem jest tanatofobia, czyli paniczny lęk przed śmiercią lub tanatofilia - rozmiłowanie w śmierci". Podczas konferencji wystąpili pracownicy katedry: ks. Józef Zabielski z referatem pt.: „Opieka hospicyjna jako służba życiu”, ks. A. Skreczko z referatem pt.: „Śmierć jako sprawdzian dla żyjących” i ks. Andrzej Proniewski, który wygłosił referat pt.: „Godność osoby cierpiącej i umierającej". Interdyscyplinarny charakter konferencji dał uczestnikom nie tylko możliwość zapoznania się z medycznymi aspektami śmierci, lecz przede wszystkim pozwolił poznać filozoficzne spojrzenie na śmierć, dostrzec godność osoby cierpiącej i umierającej, spojrzeć na śmierć jako próbę miłości czy najważniejszy moment życia ludzkiego.

"Otoczmy troską życie” to hasło tegorocznego tzw. zjazdu kolędowego - sesji naukowej skierowanej do osób duchownych i katechetów świeckich archidiecezji białostockiej organizowanej każdego roku przez Katedrę Teologii Katolickiej UwB. Otwierając dnia 10 stycznia 2009 roku w sali białostockiego kina „Ton” obrady ks. abp E. Ozorowski w kilku słowach, określił cel i wyjaśnił charakter tegorocznej debaty: „Tematyka tego spotkania jest jednocześnie tematyką roku duszpasterskiego. Życie jest zarazem dane i zadane, życie stanowi o człowieku, a człowiek żyje, aby mieć życie wieczne". Naukową część sesji wypełniły trzy referaty i dyskusja nad ich przesłaniem. Dyrektor Instytutu Studiów nad Rodziną Uniwersytetu Kardynała Stefana Wyszyńskiego w Warszawie (ISnR UKSW) ks. prof. Mieczysław Ozorowski w referacie pt.: „Życie jest z Boga” w zasadniczej części swego rozważania przekonywał, że pytanie o sens życia i o jego istotę zawsze będzie wymykać się spod możliwości poznawczych ludzkiego umysłu nawet gdyby nauce udało się uchwycić na swojej płaszczyźnie jego zasadę, bo - jak stwierdził - „podłoże godności każdego człowieka znajduje się w fakcie stworzenia na obraz i podobieństwo Boga oraz w możliwości jedności i komu- 
nii z Bogiem”. Ksiądz prof. Ireneusz Mroczkowski, pracownik naukowy ISnR na UKSW, kolejny prelegent, w referacie pt.: „Kultura życia”, apelując o „nową kulturę życia” wyjaśniał, przywołując słowa Papieża Jana Pawła II, że owa „nowa kultura życia” to "podejmowanie i rozwiązywanie nieznanych dotąd problemów" rozpoznawanych i rozwiązywanych poprzez naśladowanie Chrystusa w Jego misji prorockiej, kapłańskiej i królewskiej”. Reaktywowanie 6 stycznia 2009 roku w archidiecezji białostockiej Katolickiego Stowarzyszenia Młodzieży skłoniło organizatorów do zaproszenia na sesję asystenta generalnego KSM ks. Zbigniewa Kucharskiego, który w referacie pt.: „Otoczmy troską młodzież” wskazał na wynikającą z ducha czasu konieczność chrześcijańskiego formowania młodzieży polskiej. W jego mniemaniu: „właściwe wychowania chrześcijańskie to nie tylko formowanie religijne, ale także patriotyczne i prospołeczne”. Jest to właściwy, nadrzędny cel KSM. Tegoroczny zjazd kolędowy zaznaczył się wyjątkowo wysoką frekwencją, co dowodzi nie tylko skuteczności skrupulatnej kontroli obecności (obecność na zjeździe obowiązuje wszystkich duchownych i katechetów archidiecezji), ale także zapewne aktualnością podejmowanej problematyki.

Nowe wyzwania, jakie stają dzisiaj wobec duchownych sprawujących sakrament pokuty i pojednania legły u podstaw decyzji MKTK o zorganizowaniu dla duchownych archidiecezji białostockiej warsztatów teologiczno-moralnych. Odbyły się one w dniach 1-2 kwietnia 2009 roku w gmachu Archidiecezjalnego Wyższego Seminarium Duchownego w Białymstoku. Z wykładem wprowadzającym do pracy w grupach zaproszono kierownika Katedry Historii Teologii Moralnej UKSW, ks. bp. prof. Andrzeja Dziubę, ordynariusza łowickiego, który referatem "Życie małżeńskie a sakramentalne. Posługa pokuty i pojednania” określił charakter i problematykę warsztatów oraz podał materiał do dyskusji w zespołach. Dyskusję w grupach poprowadzili księża: Józef Zabielski, Dariusz Wojtecki i Józef Kozłowski. Ponieważ dwudniowe zajęcia spotkały się z żywym zainteresowaniem duchownych, postanowiono kontynuować tego rodzaju spotkania pod potronatem MKTK w latach następnych.

Rok Świętego Pawła (2009) i przypadająca akurat w tym roku 1000. rocznica męczeńskiej śmierci św. Brunona z Kwerfurtu określiły charakter i problematykę zorganizowanej po raz kolejny przez MKTK sesji naukowej w ramach tzw. zjazdu paschalnego 25 kwietnia 2009 roku pod hasłem „Świadkowie wiary”. Obrady, na które przybyło kilkuset księży i katechetów świeckich z terenu archidiecezji białostockiej, odbyły się w sali kina Ton w Białymstoku. Zebrani wysłuchali dwóch referatów odnoszących się kolejno do św. Brunona i do św. Pawła z Tarsu. W wystąpieniu zatytułowanym „Święty Brunon - Boży interpretator rzeczywistości” prelegent, ks. abp dr Wojciech Ziemba, metropolita warmiński, wskazał na biblijne podstawy funkcji prorockiej, po czym odnosząc się do wybranych wydarzeń z życia św. Brunona podkreślił, iż jego 
działalność i nauka nie dezaktualizuje się także dzisiaj, a jego słowa $\mathrm{z}$ identyczną mocą, prawidłowo odczytane, jak niegdyś, mogą oddziaływać na jednostki i społeczeństwa XXI stulecia. Ksiądz dr Andrzej Najda, wykładowca UKSW, w referacie „Święty Paweł a areopagi współczesności” biorąc za punkt wyjścia wystąpienie Apostoła Narodów na ateńskim areopagu, odniósł się do metod głoszenia Chrystusa dzisiaj w miejscach i instytucjach, które w swej istocie są rzeczywistościami na wskroś publicznymi. Określił je mianem współczesnych areopagów. Wśród nich wymienił prasę, telewizję, internet, urzędy, miejsca pracy oraz widowiska związane $\mathrm{z}$ funkcjonowaniem subkultur. Są to miejsca, gdzie możliwa i konieczna jest ewangelizacja. Współczesny świadek Chrystusa znajduje tu wzór w postaci Pawła z Tarsu, który nie stronił od trudnych tematów przy jednoczesnej postawie braku jakiegokolwiek kompromisu ze złem. Ucztę ową intelektualną podsumował w słowie końcowym ks. abp E. Ozorowski. Stwierdził, że: „spotykamy się nie tylko, żeby się uczyć, ale aby być razem. Ta komunia potrzebna jest każdemu. (...) Spotkanie to okazja do odnalezienia ducha, do odnalezienia siebie we wspólnocie z innymi”. Organizowane przez MKTK zjazdy: paschalny i kolędowy, w Kościele białostockim mające już ponad półwiekową tradycję, wpisują się także w permanentną formację intelektualną tak osób duchownych, jak i świeckich.

Rok 2009 z racji 200. rocznicy urodzin Juliusza Słowackiego i 160. rocznicy jego śmierci ogłoszony uchwałą Sejmu RP z 9 stycznia Rokiem Juliusza Słowackiego zmotywował białostockie środowisko uniwersyteckie do zorganizowania poświęconej Poecie międzynarodowej konferencji naukowej pod hasłem „Piękno Słowackiego”. Pracownicy MKTK włączyli się aktywnie w organizację tego przedsięwzięcia, powierzając ks. T. Kasabule funkcję koordynacji działań Katedry w ramach przygotowań do wspomnianego wydarzenia. Efekt tych wysiłków to zgromadzenie w dniach 6-9 maja 2009 roku ok. 100 prelegentów $\mathrm{z}$ różnych krajów, którzy obradując w kilku sekcjach uczcili i przypomnieli jednego $\mathrm{z}$ najwybitniejszych $\mathrm{w}$ dziejach literatury polskiej poetę. Podczas uroczystości otwarcia konferencji w auli Wydziału Prawa UwB głos zabrał kierownik MKTK, ks. abp E. Ozorowski. W krótkim wystąpieniu wskazał na miejsce i rolę Słowackiego w kulturze polskiej, której - co podkreślił Arcybiskup Metropolita Białostocki - nie da się oderwać ani tym bardziej zrozumieć bez religii. Dnia 8 maja ks. Arcybiskup w ramach obrad zespołu pod hasłem „Historia i Piękno” w czytelni Książnicy Podlaskiej wygłosił referat wprowadzający pt.: „Symbol jako klucz do programu poetyckiego Juliusza Słowackiego". Podczas dalszych obrad tegoż zespołu temat „Stolica Apostolska a Powstanie Listopadowe” zreferował ks. T. Kasabuła.

Katedra Teologii Katolickiej w kooperacji z Wyższą Szkołą Ekonomiczną w Białymstoku w ramach stałej współpracy tych jednostek naukowo-dydaktycznych zorganizowała zaplanowaną już w minionym roku sprawozdawczym ogól- 
nopolską konferencję naukową pod hasłem „Mężczyzna - etyka - ekonomia”. Obrady odbyły się w dniach 14-16 września 2009 roku wzorem lat ubiegłych w miejscowości Wojciech k. Augustowa. Obradowano w sali konferencyjnej miejscowego hotelu „Wojciech”. Intencją organizatorów było zwrócenie uwagi na mężczyznę w kontekście społecznym, ekonomicznym, religijnym, etycznym, prawnym i historycznym, zaś nadrzędnym celem: zebranie opinii, poglądów i ocen na temat uczestnictwa mężczyzn w życiu publicznym i zawodowym, $\mathrm{w}$ biznesie i w polityce oraz konfrontacja ich roli w życiu rodzinnym $\mathrm{z}$ rolą pełnioną przez kobiety. W toku trzydniowych obrad wyniki swych badań prezentowali przedstawiciele nauk społecznych, ekonomicznych, teologicznych i filozoficznych z kilku ośrodków naukowych. Wygłoszono 20 referatów, z których pięć zaprezentowali pracownicy MKTK: ks. abp E. Ozorowski („Teologia ojcostwa”), ks. J. Zabielski („Wspólnotowórcza rola mężczyzny”), ks. A. Proniewski („Ojcostwo fizyczne i duchowe”), ks. A. Skreczko („Mężczyzna jako wychowawca”) i ks. T. Kasabuła („Pozycja społeczna mężczyzny na ziemiach polskich w XIX wieku"). Podkreślić należy, że cykliczność tychże spotkań to owoc ich wysokiej oceny merytorycznej, czego dowodem są m.in. znane w świecie naukowym i poszukiwane publikacje pod wspólną redakcją naukową abp. prof. E. Ozorowskiego i prof. Ryszarda Horodeńskiego. Treści zaprezentowane podczas konferencji tegorocznej, wzorem lat ubiegłych, także zostaną opublikowane, w osobnej pozycji książkowej.

Stałym tematem spotkań roboczych pracowników Katedry w minionym roku akademickim była problematyka zaplanowanego na 26-28 września 2009 roku Kongresu Miłosierdzia w archidiecezji białostockiej, której głównym organizatorem, obok Kurii Metropolitalnej Białostockiej, jest Katedra Teologii Katolickiej, odpowiedzialna za naukową część Kongresu - konferencję popularnonaukową przewidzianą na 26 maja. Obrady, pod hasłem „Miłosierdzie Boże w życiu Kościoła”, którymi zainaugurowano trzydniowe obchody III Archidiecezjalnego Kongresu Miłosierdzia Bożego połączone z dyskusją panelową odbyły się w sali kina „Ton”. Uczestnicy wysłuchali dwóch referatów. Pierwszy w kolejności chronologicznej wygłosił ks. J. Zabielski. W refleksji, której nadał tytuł „Miłosierdzie jako personalistyczna zasada życia społecznego” wychodząc od biblijnego rozumienia miłosierdzia wskazał na nierozerwalny jego związek z pojęciem empatii, rozumianym jako zdolność patrzenia oczyma potrzebującego na jego sytuację życiową. Tylko wówczas możliwy będzie swoisty etos miłosierdzia, czyli stała dyspozycja i pragnienie czynienia dobra bliźniemu. W referacie „Boże miłosierdzie w dążeniu św. Faustyny Kowalskiej i w teologii bł. Michała Sopoćki” ks. dr hab. Jan Machniak, prof. Papieskiej Akademii Teologicznej w Krakowie, zestawił ze sobą wewnętrzne pojmowanie przymiotu Boga przez św. Faustynę i głębokie studium teologiczne nad Bożym miłosierdziem bł. Michała Sopoćki. Zorganizowany po części referatowej panel dyskusyjny dał 
uczestnikom możliwość wysłuchania opinii i świadectw osób, które, poprzez pracę w instytucjach świadczących dobro potrzebującym na co dzień zajmują się realizacją przesłania o miłosierdziu względem bliźniego.

W minionym roku akademickim zakończyła się kolejna edycja funkcjonujących przy MKTK pod kierunkiem ks. A. Proniewskiego Podyplomowych Studiów Doskonalenia Katechetycznego (PSDK). Uroczyste zakończenie Studiów i wręczenie dyplomów odbyło się 10 stycznia 2009 roku w gmachu Kurii Metropolitalnej Białostockiej. Dyplomy ukończenia studium odebrało 26 absolwentów. Ksiądz Arcybiskup pozytywnie ocenił wyniki tej formy permanentnego kształcenia duchowieństwa, a ponieważ ks. Proniewski w ocenie pracowników MKTK dobrze sprawdził się w roli koordynatora owego dzieła, Kierownik Katedry zlecił mu kierownictwo także nowej edycji PSDK w roku akademickim 2009/2010. Nowy semestr rozpoczęło 36 studentów.

Paląca potrzeba kształcenia i doskonalenia zawodowego nauczycieli etyki dla szkół legła u podstaw wszczęcia wstępnych rozmów z władzami Wydziału Pedagogiki i Psychologii UwB w celu powołania odpowiedniego studium podyplomowego dla podniesienia poziomu nauczania tego przedmiotu. Delegowany przez kierownika Katedry do przeprowadzenia wstępnego sondażu $\mathrm{w}$ tej sprawie ks. A. Skreczko odbył rozmowę z dziekan Wydziału prof. Elwirą Kryńską i prodziekan ds. studiów dziennych dr Anną Kienig. Wynikiem rozmów wstępnych była wspólna decyzja MKTK i władz Wydziału o powołaniu Podyplomowych Studiów z Etyki, na których pracownicy Katedry podjęliby zajęcia $\mathrm{z}$ następujących dziedzin: zagadnienia moralne współczesności, etyka, historia etyki, etyka indywidualna i społeczna, historia filozofii, antropologia, etyka normatywna. Ksiądz Skreczko został upoważniony przez Kierownika MKTK do pilotowania etapu organizacyjnego rzeczonego Studium.

W minionym roku akademickim Nagrodę Rektora UwB za 10 lat przykładnej pracy otrzymała s. Anna Tyra (OSU) pracownik administracyjny MKTK. Ponieważ zaś s. Anna osiągnęła właśnie stosowny wiek, podjęła decyzję o przejściu na emeryturę od 1 czerwca 2009 roku. Uroczyste jej pożegnanie miało miejsce na posiedzeniu pracowników Katedry 19 maja 2009 roku. Ksiądz Arcybiskup w imieniu własnym i pozostałych pracowników MKTK przekazał wyrazy uznania i wyraził s. Annie wdzięczność za jej dotychczasową pracę. Odśpiewano gromkie „Sto lat”, po czym w odpowiedzi s. Anna podziękowała obecnym za 10 lat owocnej współpracy i poinformowała, że wraz z przejściem na emeryturę przekaże swoje obowiązki następczyni, mgr teologii Annie Dzięgielewskiej oraz w obecności i przy udziale pracownika sekcji inwentaryzacji UwB dokona formalnego przekazania kompletnego inwentarza jednostki. Zgodziła się też chętnie wprowadzić nowego pracownika w zawiłości pracy administracyjnej.

Wysiłkiem pracowników MKTK ukazał się kolejny, siódmy tom pisma Katedry „Rocznik Teologii Katolickiej” pod redakcją ks. A. Skreczki poświęcony 
pamięci Sługi Bożego, obecnie błogosławionego ks. Michała Sopoćki ze słowem wstępnym abp. E. Ozorowskiego, Metropolity Białostockiego. W przygotowaniu jest tom ósmy czasopisma.

Pracownicy MKTK, jako jednostki naukowo-badawczej w strukturach UwB prowadzili w minionym roku akademickim przewidzianą $\mathrm{w}$ ramach ich pensum działalność dydaktyczną prowadząc wykłady kursowe i monograficzne, konwersatoria, ćwiczenia i seminaria naukowe na różnych wydziałach UwB. W ramach działalności statutowej kontynuowali prace badawcze w swoich dziedzinach, organizowali, współorganizowali i uczestniczyli w zjazdach, sympozjach i konferencjach naukowych, dzieląc się tym samym wynikami badań mieszczących się w obszarach ich zainteresowań, zarówno na forum krajowym, jak i za granicą. Wynikiem owej aktywności jest dorobek piśmienniczy w postaci druków samoistnych, publikacji przez nich redagowanych, artykułów naukowych i popularnonaukowych, recenzji i sprawozdań zamieszczanych w czasopismach naukowych i popularnonaukowych krajowych i zagranicznych. Pełny wykaz publikacji pracowników MKTK zamieszczany jest regularnie na stronie internetowej Katedry (www.ktk.uwb.edu.pl) oraz w wykazie publikacji wykładowców AWSD w Białymstoku zamieszczanym co roku w kwartalniku kurii metropolitalnej białostockiej („Wiadomości Kościelne Archidiecezji Białostockiej", 40: 2009, nr 4).

Podczas cyklicznych spotkań roboczych wszystkich pracowników MKTK są prowadzone dyskusje, których celem jest podsumowanie i ocena dotychczasowej działalności jednostki, opracowanie nowych projektów i inicjatyw badawczych oraz koordynacja przedsięwzięć już realizowanych.

ks. Tadeusz Kasabuła Uniwersytet $w$ Białymstoku 